\title{
PENGARUH PENGAWASAN TERHADAP DISIPLIN KERJA PEGAWAI PADA SMAN 13 DI BANDAR LAMPUNG
}

\author{
Edi Santosa ${ }^{(1)}$, Kuswarak $^{(2)}$, Iwan Zulfikar ${ }^{(3)}$ \\ Fakultas Ekonomi Universitas Sang Bumi Ruwa Jurai \\ edi.santosa23@gmail.com,kuswarak@fe.saburai.ac.id,iwan.zulfikar@fe.saburai.ac.id
}

\begin{abstract}
Abstrak. Pengawasan yang dilakukan dengan baik, maka pekerjaan akan berjalan dengan lancar dan dapat menghasilkan hasil kerja yang baik pula. Selain itu, melalui pengawasan dapat dipantau berbagai hal yang dapat merugikan organisasi antara lain kesalahan dalam pekerjaannya, kekurangan dalam pelaksanaan pekerjaan, kelemahan pelaksanaan dan cara kerjanya. Disiplin kerja pegawai yang rendah akan mempengaruhi kinerja pegawai, Faktor-faktor yang mempengaruhi kinerja pegawai disebabkan oleh disiplin kerja dan pengawasan. Berdasarkan hasil Uji t didapat nilai $\mathrm{t}$ hitung $=19,041$ dan setelah dibandingkan dengan $t$ tabel pada taraf signifikan 95\% yaitu 2,66, maka thitung $=19,041>t$ tabel $=2,66$, sehingga dapat diketahui bahwa Ha yang menyatakan terdapat pengaruh antara variabel Pengawasan (X) terhadap Disiplin Kerja Pegawai (Y) dapat diterima. Jadi variabel Pengawasan $(\mathrm{X})$ berpengaruh terhadap variabel Disiplin Kerja Pegawai (Y). Kemudian pada persamaan regresi antara variabel Pengawasan $(\mathrm{X})$ terhadap variabel Disiplin Kerja Pegawai $(\mathrm{Y})$ adalah $\mathrm{Y}=0,154+0,990 \mathrm{X}$. Disiplin Kerja Pegawai akan meningkat sebesar $0,154 \%$. Bx $=0,990$ yang dapat dinyatakan bahwa setiap penambahan tanggapan responden mengenai pengawasan, maka dapat diikuti oleh Disiplin Kerja Pegawai sebesar 99,0\% atau setiap terjadi peningkatan nilai pada variabel pengawasan sebesar satu point, maka Disiplin Kerja Pegawai akan meningkat sebesar 0,990 point.
\end{abstract}

Kata kunci: Disiplin, Kerja, Pegawai, Pengawasan.

\section{PENDAHULUAN}

Disiplin kerja merupakan suatu proses perkembangan konstruktif bagi pegawai yang berkepentingan karena disiplin kerja ditunjukan pada tindakan bukan orangnya. Disiplin juga sebagai proses latihan pada pegawai agar para pegawai dapat mengembangkan kontrol diri dan agar dapat menjadi lebih efektif dalam bekerja. Dengan demikian tindakan pendisiplinan juga hendaknya mempunyai sasaran yang positif, bersifatnya mendidik dan mengoreksi, bukan tindakan negatif yang menjatuhkan pegawai atau bawahan yang indisipliner dengan maksud tindakan pendisiplinan untuk memperbaiki efektifitas dalam tugas dan pergaulan sehari-hari di masa yang datang bukan menghukum kegiatan masa lalu.

Disiplin kerja pegawai negeri mutlak harus dijalankan dan ditegakkan demi tumbuh berkembangnya suatu aparatur pemerintah dalam mengamalkan tugas dan tangung jawab yang telah dipercayakan bangsa dan Negara kepada pegawai negeri oleh karena itu sudah menjadi kewajiban setiap pegawai untuk menegakkan disiplin.

Dalam Undang-undang nomor 43 Tahun 1949 tentang perubahan atas Undang-undang nomor 8 Tahun 1974 tentang Pokok-Pokok Kepegawaian bahwa "peraturan disiplin adalah suatu peraturan yang membuat keharusan, larangan dan sanksi, apabila keharusan tidak dituruti atau larangan dilanggar. Untuk menjamin tata tertib dan kelancaran pelaksanaan tugas maka dengan tidak mengurangi ketentuan dalam peraturan perundang-undangan pidana diadakan disiplin pegawai negeri sipil”.

Pengawasan merupakan tindakan atau kegiatan yang dilakukan oleh pimpinan untuk mengetahui apakah jalannya pekerjaan dan hasilnya sesuai dengan rencana. Kinerja juga sangat dipengaruhi 
oleh tingkat pengawasan pada saat jam kerja sedang berlangsung. Pengawasan yang tidak optimal dapat memungkinkan pegawai untuk bertindak semaunya sendiri bahkan bisa melakukan pelanggaran yang bertentangan dengan aturan yang berlaku di perusahaan.

Penerapan disiplin merupakan hal yang harus diperhatikan dalam pelaksanaan pekerjaan, dengan kata lain disiplin itu bukan sekedar kepatuhan terhadap perintah akan tetapi sebagai suatu sikap serta perbuatan yang timbul dari dalam diri pegawai untuk bertanggung jawab serta mengikuti kewajiban dan peraturanperaturan yang dibentuk sehingga tanggung jawab melekat pada disiplin tersebut maupun mempengaruhi tugas-tugas yang dilaksanakan.

Berdasarkan pengamatan yang dilakukan peneliti di SMA Negeri 13 Bandar Lampung bahwa pengawasan yang dilakukan atasan terhadap pegawai masih kurang efektif, tidak menetapkan standar waktu untuk mengukur kinerja pegawai, atasan kurang tegas dalam memberikan peringatan dan sanksi apabila ada pegawai yang melakukan kesalahan atau penyimpangan, dan pengawasan yang dilakukan atasan tidak setiap hari.

Salah satu yang mempengaruhi kinerja pegawai adalah disiplin kerja. Disiplin kerja pegawai SMA Negeri 13 Bandar Lampung adalah $40 \%$ pegawai sering datang terlambat masuk kerja, $20 \%$ pegawai yang tidak masuk kerja dengan alasan diluar urusan pekerjaan kantor, $45 \%$ pegawai yang tidak tepat waktu dalam melaksanakan pekerjaannya.

Pengawasan merupakan salah satu faktor untuk menentukan kinerja pegawai. Pengawasan yang baik akan memberikan efek yang baik pula karena pegawai akan menyelesaikan pekerjaan tepat waktu sesuai dengan target waktu pekerjaan yang ditetapkan. Menurut peneliti pengawasan penting di SMA Negeri 13 Bandar Lampung karena masih ada pegawai yang melakukan kesalahan dan pelanggaran sehingga visi dan misi dari sekolah tidak akan tercapai.

Peneliti mengangkat variabel pengawasan merupakan faktor yang mempengaruhi kinerja pegawai pada SMA Negeri 13 Bandar Lampung, karena tanpa adanya pengawasan suatu instansi akan gagal, apabila tidak adanya pengawasan dari atasan atau kurang aktifnya atasan dalam mengawasi pekerjaan para pegawai dan pelayanan terhadap murid-murid sekolah akan terbengkalai sehingga visi misi dan tujuan dari sekolah tersebut tidak akan tercapai.

Disiplin kerja pegawai di SMA Negeri 13 Bandar lampung antara lain adalah $40 \%$ pegawai masih sering terlambat masuk kerja karena di kantor itu sistem absen pegawai masih menggunakan manual, walaupun pegawai terlambat maka atasan tidak akan mengetahuinya karena pegawai yang terlambat akan menyuruh temannya yang datang lebih dulu untuk membuat tanda tangan absennya. $20 \%$ pegawai yang tidak masuk kerja dengan alasan diluar urusan pekerjaan kantor, atasan tidak mengetahui bahwa pegawai tidak masuk kerja karena atasan kurang aktif dalam mengawasi pegawai apakah semua pegawai hadir pada saat waktu bekerja dan melakukan tugas dan pekerjaan yang diberikan kepada pegawai. $40 \%$ pegawai yang tidak tepat waktu dalam melaksanakan pekerjaannya mengakibatkan pekerjaan menumpuk dan pegawai mengalami kendala dalam pekerjaannya sehingga visi dan misi dari kantor itu tidak tercapai.

Berdasarkan uraian tersebut di atas, penulis tertarik untuk menelitinya lebih lanjut dengan judul: "Pengaruh Pengawasan Terhadap Disiplin Kerja Pegawai Pada SMAN 13 Bandar Lampung". 


\section{KAJIAN TEORI}

\section{Pengertian Pengawasan}

Pengawasan menurut Mc. Farland, yang dikutip oleh Soewarno Handayaningrat (2005) yaitu pengawasan ialah suatu proses dimana pimpinan ingin mengetahui apakah hasil pelaksanaan pekerjaan yang dilakukan oleh bawahannya sesuai dengan rencana, perintah, tujuan, atau kebijaksanaan yang telah dikemukakan. George R. Terry yang dikutip oleh Sujamto (2003), mengemukakan bahwa pengawasan yaitu pengawasan adalah untuk menentukan apa yang telah dicapai, mengadakan evaluasi atasannya, dan mengambil tindakantindakan korektif bila diperlukan untuk menjamin agar hasilnya sesuai dengan rencana.

Sementara menurut Manullang (2009) pengawasan yaitu pengawasan adalah suatu proses untuk menerapkan pekerjaan apa yang sudah dilaksanakan, menilainya, dan bila perlu mengoreksi dengan maksud supaya pelaksanaan pekerjaan sesuai dengan rencana semula. Sedangkan menurut Hani Handoko (2014) mengatakan bahwa pengawasan dapat didefinisikan sebagai proses untuk menjamin bahwa tujuan-tujuan organisasi dan manajemen tercapai.

Henry Fayol yang di kutip oleh Manullang (2009) mengatakan pengawasan yaitu pengawasan terdiri dari pengujian apakah segala sesuatu berlangsung sesuai dengan rencana yang telah ditentukan, dengan instruksi yang telah diberikan dan dengan prinsip-prinsip yang telah digariskan. Ia bertujuan untuk menemukan kelemahan-kelemahan dan kesalahankesalahan dengan maksud untuk memperbaikinya dan mencegah terulangnya kembali.

\section{Maksud, Tujuan dan Fungsi Pengawasan}

Pengawasan itu dimaksudkan untuk mencegah atau untuk memperbaiki kesalahan, penyimpangan, ketidaksesuaian, penyelewengan dan lainnya yang tidak sesuai dengan tugas dan wewenang yang telah ditentukan. Jadi maksud pengawasan bukan mencari kesalahan terhadap orangnya, tetapi mencari kebenaran terhadap hasil pelaksanaan pekerjaannya.

Tujuan pengawasan adalah agar hasil pelaksanaan pekerjaan diperoleh secara berdaya guna (efisien) dan berhasil guna (efektif), sesuai dengan rencana yang telah ditentukan sebelumnya. Fungsi pengawasan menurut Soewarno Handayanigrat (2005) mengemukakan bahwa :

a. Mempertebal rasa tanggung jawab terhadap pejabat yang diserahi tugas dan wewenang dalam pelaksanaan pekerjaan.

b. Mendidik para pejabat agar mereka melaksanakan pekerjaannya sesuai dengan prosedur yang telah ditentukan.

c. Untuk mencegah terjadinya penyimpangan, kelalaian dan kelemahan, agar tidak terjadi kerugian yang tidak di inginkan.

d. Untuk memperbaiki kesalahan dan penyelewengan, agar pelaksanaan pekerjaan tidak mengalami hambatan dan pemborosan-pemborosan.

\section{Disiplin Kerja}

Kata disiplin berasal dari bahasa latin "disicipline" yang berarti "latihan atau pendidikan kesopanan dan kerohanian serta pengembangan tabiat". Hal ini menekankan bantuan kepada pegawai untuk mengembangkan sikap yang layak terhadap pekerjaannya dan merupakan cara 
pengawas dalam membuat perannya dalam hubungannya dengan disiplin.

Pengertian disiplin menurut Moekijat (2009) adalah disiplin merupakan suatu kekuatan yang berkembang di dalam tubuh pekerja sendiri yang menyebabkan dia dapat menyesuaikan diri dengan sukarela kepada keputusan-keputusan, peraturanperaturan dan nilai-nilai tinggi dari pekerjaan dan tingkah laku.

Terdapat pengertian lain mengenai disiplin menurut Malayu S.P Hasibuan (2007) mengungkapkan bahwa kedisiplinan adalah kesadaran dan kesediaan seseorang menaati semua peraturan perusahaan dan norma-norma yang berlaku. Kesadaran adalah sikap seseorang yang secara sukarela menaati semua peraturan dan sadar akan tugas dan tanggung jawabnya. Kesediaan adalah suatu sikap, tingkah laku dan perbuatan seseorang yang sesuai dengan peraturan perusahaan, baik yang tertulis maupun tidak.

Rumusan lain menyatakan tentang pengertian disiplin menurut Siagian (2006), yakni disiplin merupakan tindakan manajemen mendorong para anggota organisasi memenuhi tuntutan berbagai ketentuan tersebut. Dengan perkataan lain, pendisiplinan pegawai adalah suatu bentuk pelatihan yang berusaha memperbaiki dan membentuk pengetahuan, sikap dan perilaku karyawan sehingga karyawan tersebut secara sukarela berusaha bekerja secara kooperatif dengan para karyawan yang lain serta meningkatkan prestasi kerjanya.

\section{Tujuan Disiplin Kerja}

Secara umum dapat disebutkan bahwa tujuan utama disiplin kerja adalah demi kelangsungan organisasi atau perusahaan sesuai dengan motif organisasi atau perubahan yang bersangkutan baik hari ini maupun hari esok. Menurut Siswanto Sastrohardiwiryo (2003) secara khusus tujuan disiplin kerja para pegawai antara lain :

1. Agar para pegawai menepati segala peraturan dan kenijakan ketenagakerjaan maupun peraturan dan kebijakan organisasi yang berlaku, baik tertulis maupun tidak tertulis, serta melaksanakan perintah manajemen yang baik.

2. Pegawai dapat melaksanakan pekerjaan dengan sebaik-baiknya serta mampu memberikan pelayanan yang maksimum kepada pihak tertentu yang berkepentingan dengan organisasi sesuai dengan bidang pekerjaan yang diberikan kepadanya.

3. Pegawai dapat mengemukakan dan memelihara sarana dan prasarana, barang dan jasa organisasi dengan sebaik-baiknya.

4. Para pegawai dapat bertindak dan berpartisipasi sesuai dengan normanorma yang berlaku pada organisasi.

5. Pegawai mampu menghasilkan produktivitas yang tinggi sesuai dengan harapan organisasi, baik dalam jangka pendek maupun jangka panjang.

\section{METODE PENELITIAN}

\section{Objek Penelitian}

Objek penelitian dalam penelitian ini adalah Pegawai SMA Negeri 13 Bandar Lampung, SMA Negeri 13 Bandar Lampung adalah salah satu SMA yang termuda di Kotamdaya Daerah Tingkat II Bandar Lampung yang berdiri pada tanggal 01 April 1996, yang semula masih menumpang di SMA Negeri 12 Bandar Lampung dengan lokasi di jalan Hendro Suratmin Sukarame, Bandar Lampung 
Penelitian ini dilakukan dari bulan Februari sampai dengan Mei 2016.

\section{Metode dan Teknik Pengumpulan Data}

Metode pengumpulan data yang digunakan dalam penulisan ini yaitu, data primer dan data sekunder.

1. Data Primer

Data primer merupakan data yang diperoleh langsung tanpa perantara orang atau lembaga lain sebai pihak ketiga. Data primer ini diperoleh dengan wawancara melalui responden dengan menggunakan daftar pertanyaan dalam hal ini diperoleh langsung dari pegawai SMAN 13 Bandar Lampung.

2. Data Sekunder

Merupakan data yang diperoleh melalui orang lain yang berhubungan dengan permasalahan yang dipecahkan. Data sekunder ini diperoleh melalui cara studi dokumenter yaitu mengumpulkan adn mempelajari brosur-brosur serta dokumendokumen, catatan-catatan dan arsip perusahaan.

Adapun teknik yang digunakan dalam pengumpulan data adalah dengan :

1. Observasi, yaitu mengadakan survey atau pengamatan langsung kelokasi penelitian.

2. Interview atau wawancara, yaitu mengadakan tanya jawab langsung dengan pegawai SMAN 13 Bandar Lampung.

3. Dokumentasi, yaitu mengumpulkan dan mencatat dokumentasi yang relevan.

4. Kuisioner, yaitu membuat pertanyaan yang berhubungan dengan variabel penelitian.

\section{Sampel dan Populasi}

Sampel adalah sebagian dari jumlah dan karakteristik yang dimiliki oleh populasi tersebut. Sampel adalah sebagian dari jumlah dan karakteristik yang dimiliki populasi tersebut makin besar jumlah sampel mendekati populasi, maka peluang kesalahan generalisasi semakin kecil dan sebaliknya semakin kecil jumlah sampel menjauhi populasi, maka semakin besar kesalahan generasilasi. (Suharsimi Arikunto, 2010). Dalam penelitian ini peneliti mengambil sampel sebanyak 40 orang pegawai SMA Negeri 13 Bandar Lampung.

\section{Metode Analisis Data}

Analisis kualitatif, yaitu menganalisis permasalahan dengan cara membandingkan antara teori dengan permasalahan yang dihadapi oleh SMAN 13 Bandar Lampung.

Analisis kuantitatif, yaitu menganalisis hubungan dengan menggunakan metode statistik.

Persamaan Regresi Linear Sederhana menentukan persamaan regresi linear sederhana untuk X :

$$
Y=a+b X+e
$$

Keterangan:

$$
\begin{aligned}
& \mathrm{Y}=\text { Disiplin kerja } \\
& \mathrm{a}=\text { Konstanta } \\
& \mathrm{b}=\text { Koefisien regresi } \mathrm{X} \\
& \mathrm{X}=\text { Pengawasan } \\
& \mathrm{e}=\text { Faktor kesalahan }
\end{aligned}
$$

Untuk mengetahui besarnya pengaruh, penghitungan koefisien korelasi tersebut kemudian dilanjutkan dengan Rumus Koefisien Determinasi atau Koefisien Penentu (KP):

$$
K P=(r)^{2} x 100 \%
$$


Untuk menguji secara hipotesis secara parsial digunakan Uji t dengan rumus :

$$
t_{\text {hitung }}=\frac{r \sqrt{N-2}}{\sqrt{1-r^{2}}}
$$

Keterangan:

$$
\begin{array}{ll}
\mathrm{t}_{\text {hitung }} & =\text { Nilai } \mathrm{t} \\
\mathrm{r} & =\text { Koefisien Korelasi } \\
\mathrm{N} & =\text { Jumlah responden }
\end{array}
$$

Kriteria untuk Uji $\mathrm{t}$ adalah sebagai berikut :

a) Jika $t_{\text {hitung }}>t_{\text {tabel }}$ maka Ha diterima dan Ho ditolak.

b) Jika $t_{\text {hitung }} \leq \mathrm{t}_{\text {tabel }}$ maka Ha ditolak dan Ho diterima.

\section{HASIL DAN PEMBAHASAN}

\section{Analisis Kualitatif}

Uji Validitas (kesesuaian) ini dipergunakan untuk mengetahui tingkat kesesuaian dari instrumen kuesioner yang digunakan dalam pengumpulan data. Ujia validitas ini dilakukan untuk mengetahui apakah item-item yang tersaji dalam kuesioner benar-benar mampu mengungkapkan dengan pasti apa yang akan diteliti. agar dianggap memenuhi syarat valid adalah dengan mengkorelasikan masing-masing dengan skor total variabel.

Kemudian angka korelasi yang dihasilkan akan dibandingkan dengan nilai $r$ tabel pada $\mathrm{a}=0,05$ dengan df (degre of freedom $)=40$ yaitu sebesar 0,318. Dengan demikian berdasarkan uji validitas maka butir dalam instrumen tersebut dinyatakan valid apabila nilai $t$ hitung skor item terhadap skor totalnya lebih besar $(>)$ dari 0,318 atau dikatakan tidak valid apabila nilai t hitung skor item terhadap sekor totalnya lebih kecil $(<)$ dari 0,318. oleh karenanya, semakin baik nilai koefisien korelasi person suatu item,

\begin{tabular}{|c|c|c|c|c|}
\hline No & Variabel & $\mathrm{r}_{\text {hitung }}$ & $r_{\text {tabel }}$ & Keterangan \\
\hline \multirow[t]{11}{*}{1} & Pengawasan & & & \\
\hline & & 0.886 & 0,318 & Valid \\
\hline & & 0.758 & 0,318 & Valid \\
\hline & & 0.777 & 0,318 & Valid \\
\hline & & 0.680 & 0,318 & Valid \\
\hline & & 0.379 & 0,318 & Valid \\
\hline & & 0.562 & 0,318 & Valid \\
\hline & & 0.260 & 0,318 & Invalid \\
\hline & & 0.228 & 0,318 & Valid \\
\hline & & 0.562 & 0,318 & Valid \\
\hline & & 0.638 & 0,318 & Valid \\
\hline \multirow[t]{11}{*}{2} & Disiplin & & & \\
\hline & & 0.878 & 0,318 & Valid \\
\hline & & 0.741 & 0,318 & Valid \\
\hline & & 0.821 & 0,318 & Valid \\
\hline & & 0.656 & 0,318 & Valid \\
\hline & & 0.423 & 0,318 & Valid \\
\hline & & 0.696 & 0,318 & Valid \\
\hline & & 0.330 & 0,318 & Valid \\
\hline & & 0.420 & 0,318 & Valid \\
\hline & & 0.424 & 0,318 & Valid \\
\hline & & 0.580 & 0,318 & Valid \\
\hline
\end{tabular}

pengujian validitas selengkapnya dapat dilihat pada Tabel 1 .

Tabel 1. Hasil Pengujian Validitas

Berdasarkan data pada Tabel 1. terlihat bahwa korelasi antara masing- masing indikator terhadap total skor konstruk dari setiap variabel menunjukkan hasil yang signifikan dan hanya satu pada variabel promosi yang lebih kecil, sehingga menunjukkan bahwa $\mathrm{r}$ hitung $>\mathrm{r}$ tabel. atau dapat disimpulkan bahwa hampir semua item pertanyaan dinyatakan valid.

Uji Reliabilitas (keterpercayaan) yang dipergunakan adalah untuk mengetahui layak tidaknya data responden yang digunakan dalam penelitian. Reliabilitas pernyataan variabel pengawasan ditunjukan pada tabel 6 dengan jumlah responden ( $N$ of Cases) sebesar 40 dan jumlah item pernyataan ( $N$ of items) alpha total sebesar 0,768. dari 10 item pertanyaan nilai alpha 
of item deleted seluruhnya menunjukkan reliabel, karena nilai 10 item pernyataan lebih dari 0,665.

\section{Analisis Kuantitatif}

Persamaan regresi antara variabel pengawasan $(\mathrm{X})$ terhadap variabel disiplin Kerja (Y) adalah $\mathrm{Y}=0,154+0,990 \mathrm{X}$. Koefisien Determinasi $=\mathrm{R} 2=0,9512=$ $0,905=0,905 \times 100=90,5 \%$. Dapat disimpulkan bahwa variabel pengawasan menjelaskan variasi perubahan terhadap variabel disiplin kerja pada SMAN 13 Bandar Lampung sebesar 90,5\%, sedangkan sisanya dijelaskan oleh faktor lain yang tidak dikaji dalam penelitian ini.

Berdasarkan hasil Uji $t$ didapat nilai $\mathrm{t}$ hitung $=19,041$. Apabila dibandingkan dengan $\mathrm{t}$ tabel pada taraf signifikan $95 \%$ yaitu 2,66, maka $\mathrm{t}$ hitung = 19,041> $\mathrm{t}$ tabel $=2,66$ sehingga dapat disimpulkan bahwa : Ha yang menyatakan terdapat pengaruh antara variabel Pengawasan (X) terhadap Disiplin Kerja (Y) dapat diterima. Jadi variabel Pengawasan (X) berpengaruh terhadap variabel Disiplin Kerja (Y).

Sedangkan berdasarkan hasil penelitian, diperoleh koefisien determinasi pengawasan terhadap disiplin kerja pegawai adalah apabila merujuk dari hasil pembahasan berkenaan dengan pengaruh antara pengawasan dan disiplin kerja pegawai SMAN 13 Bandar Lampung dimana berdasarkan hasil Uji t didapat nilai t hitung $=19,041$ dan setelah dibandingkan dengan $\mathrm{t}$ tabel pada taraf signifikan 95\% yaitu 2,66, maka t hitung $=19,041>\mathrm{t}$ tabel $=2,66$ sehingga dapat disimpulkan bahwa : Ha yang menyatakan terdapat pengaruh antara variabel pengawasan (X) terhadap disiplin kerja pegawai (Y) dapat diterima. Jadi variabel pengawasan (X) berpengaruh terhadap variabel disiplin kerja pegawai (Y).
Menurut hemat penulis, besarnya nilai t hitung $=19,041$ adalah karena pengawasan ini terkesan lemah dan kalaupun ada pengaruh pengawasan terhadap disiplin kerja pegawai baru menampakkan peningkatan. Hal ini dibuktikan dengan perhitungan pada Koefisien Determinasi $=$ $\mathrm{R} 2=0,9512=0,905=0,905 \times 100=$ 90,5\%. Dapat disimpulkan bahwa variabel disiplin kerja pegawai menjelaskan variasi perubahan terhadap variabel pengawasan sebesar 90,9\%, dan persamaan regresi antara variabel pengawasan $(\mathrm{X})$ terhadap variabel disiplin kerja pegawao (Y) adalah $\mathrm{Y}=0,154+0,990 \mathrm{X}$.

Dimana bo $=0,154$ merupakan nilai konstanta atau yang dapat diartikan bahwa promosi bernilai konstan, maka bila setiap terjadi peningkatan nilai pada variabel pengawasan sebesar satu point, berakibat disiplin kerja pegawai hanya akan meningkat sebesar $0,154 \%$. $\mathrm{Bx}=0,990$ yang dapat dinyatakan bahwa setiap penambahan tanggapan responden mengenai pengawasan, maka dapat diikuti oleh disiplin kerja pegawai sebesar satu point, maka disiplin kerja pegawai akan meningkat sebesar 0,990 point, artinya pengawasan akan berjalan baik jika disiplin kerja baik dan ini akan meningkatkan point sebesar 0,990. Bila pengawasan baik, maka setidaknya disiplin kerja pegawai pada SMAN 13 Bandar Lampung dapat berjalan dengan baik.

\section{KESIMPULAN DAN SARAN}

\section{Kesimpulan}

Berdasarkan penelitian dan pembahasan yang telah dilakukan maka dapat disimpulkan bahwa berdasarkan hasil Uji t didapat nilai t hitung $=19,041$ dengan $\mathrm{t}$ tabel pada taraf signifikan $95 \%$ yaitu 2,66 , maka $\mathrm{t}$ hitung $=19,041>\mathrm{t}$ tabel $=$ 2,66 menyatakan terdapat pengaruh antara variabel pengawasan (X) terhadap 
disiplin kerja pegawai (Y) dapat diterima. Jadi variabel pengawasan $(\mathrm{X})$ berpengaruh terhadap variabel disiplin kerja pegawai (Y). Kemudian persamaan regresi antara variabel pengawasan $(\mathrm{X})$ terhadap variabel disiplin kerja pegawai $(\mathrm{Y})$ adalah $\mathrm{Y}=0,154$ $+0,990 \mathrm{X}$

\section{Saran}

Berdasarkan kesimpulan yang telah dikemukakan diatas maka, maka peneliti dapat memberikan saran sebagai berikut :

1. Hendaknya kondisi yang dicapai oleh SMAN 13 Bandar Lampung pada saat ini terus dipertahankan dimasa-masa mendatang.

2. Hendaknya pihak SMAN 13 Bandar Lampung terus memberikan rangsangan kepada para pegawai dengan memberikan berbagai fasilitas seperti sarana dan prasarana yang memadai.

3. Hendaknya pihak SMAN 13 Bandar Lampung memberikan penghargaan / reward terhadap pegawai yang mempunyai prestasi dalam bidang pendidikan khususnya proses belajar mengajar di SMAN 13 Bandar Lampung.

\section{DAFTAR PUSTAKA}

Arikunto, Suharsimi. 2006. Prosedur Penelitian. Jakarta: Bhineka Aksara.

Handayaningrat, Suwarno. 2007. Disiplin Kerja Pegawai. Jakarta: Gramedia Pustaka.

Handoko, Hani. 2002. Manajemen. Yogyakarta: BPFE.
Hasibuan, Malayu S.P. 2013. Manajemen Sumber Daya Manusia. Jakarta: Bumi Aksara.

Komarudin. 2002. Pengendalian dan Pengawasan Kerja. Jakarta: Balai Pustaka.

Mangkunegara, Anwar Prabu. 2011. Manajemen Suatu Pengantar. Bandung: Tarsito.

Manulang. 2009. Organisasi dan Kedisiplinan. Jakarta: Erlangga.

Moekijat. 2009. Administrasi Perkantoran. Bandung: Alumni.

Siagian, S.P. 2006. Penerapan Statistik Untuk Pendidikan. Bandung: Cipta Pustaka Media Perintis.

Silalahi, Ubert. 2002. Pendidikan Dasar Organisasi.Bandung: Alumni.

Sudjana. 2002. Metode Statistik. Bandung: Tarsito.

Sugiono. 2011. Dasar-dasar Organisasi dan Manajemen. Jakarta: Ghalia Indonesia.

Supriyono. 2008. Manajemen Strategi dan Kebijaksanaan Bisnis. Yogyakarta: BPFE-UGM.

Swastha, Basu D.H. 2007. Azas-azas Martketing. Yogyakarta: AKB.

Winardi. 2008. Manajemen Pemasaran Modern. Jakarta: Grafindo. 